\title{
Municipal regulations and the use of public space: local ordinances in Italy
}

Stefano Moroni ${ }^{1 *}$ and Francesco Chiodelli ${ }^{2}$

\begin{abstract}
The article discusses the regulation of public space with specific reference to municipal by-laws. It focuses on the case of municipal "ordinances" in Italy. The basic features of the municipal by-laws will be described, and their application in recent years will be analysed. This will be followed by a critique of their particular implications concerning the use of space, with emphasis on the issue of regulating behaviour in public spaces on the basis of substantive conceptions of the "good", and on the intrinsic limitations of municipal by-laws as applied in Italy.
\end{abstract}

Keywords: Municipal law; Italy; Public space; Pluralism; Regulation

\section{Background: Urban life, public spaces, and municipal regulations ${ }^{1}$}

Local governments have always regulated urban life through the application of local regulations. Nevertheless, as Valverde (2005) has pointed out, studies on the relations between local by-laws and space are relatively recent in urban studies: the first works appeared in the mid-1990s and focused in particular on a series of measures applied in the United States and Canada ${ }^{2}$ in order to curb cases of so-called "street disorder" (begging, vagrancy, etc.). The issue is not limited to North America, however: albeit with different qualitative and quantitative features, the phenomenon occurs in certain European countries as well (Doherty et al. 2008; Wacquant, 2001; Ambrosini, 2013; Recasens et al. 2013). In this regard, developments are particularly interesting in Italy, where instances of policing city life through municipal regulations - and more specifically by means of the so-called "ordinanza municipale [municipal ordinance]" - have increased significantly in recent years: "In Italy ... there is a proliferation of ordinances, often arbitrary if not trivial, by some municipalities" (Recasens et al. 2013, p. 374).

The impact of these measures can be far-reaching. For instance, as regards the control of public space, the regulation of access and behaviour can hugely condition the way in which people live in their cities and enjoy

\footnotetext{
*Correspondence: stefano.moroni@polimi.it

'Department of Architecture and Urban Studies, Milan Polytechnic,

via Bonardi 3 - 20133, Milano, Italy

Full list of author information is available at the end of the article
}

them. It may do so, for example, by excluding or impeding particular "undesired" groups or lifestyles (Chiodelli and Moroni 2013). In fact, public spaces are fundamental nexuses of urban life (Gehl, 1996; Madanipour, 2003 and Madanipour 2010; Mitchell, 2003; Staeheli and Mitchell, 2008; Carmona et al. 2010). Hence, how their use is regulated is crucial - and not just how they are actually designed. Note also that, in most cases, municipal ordinances tend to have specific features that distinguish them from other forms of regulation of social life (such as criminal law and constitutional rights law). ${ }^{4}$ This specificity has spawned numerous debates on the legitimacy and opportunity of such forms of regulation, particularly in the United States and Canada (Ellickson, 1996; Teir, 1998; Waldron, 2000; Blomley, 2007). The purpose of this article is to extend the discussion, with particular regard to practice in Italy, which has several notable peculiarities.

\section{Case description: The municipal ordinance in Italy} 2.1. Definition and characteristics of the instrument

The municipal ordinance first appeared in Italy in the mid-1800s as a measure devised essentially to tackle unexpected and grave situations requiring an immediate response and not otherwise covered by ordinary regulatory measures. Take for example the response to catastrophic events, such as floods or earthquakes, and the related need promptly to block access to the areas affected or transit within them. ${ }^{5}$ Given the urgency of the situations with which ordinances are intended to deal, 
they are usually issued by the mayor directly. They are therefore not subject to the standard deliberative procedures (e.g., a ruling by the local council), nor to debate and the relative voting procedure. For this reasons they are atypical in nature.

Traditionally, in Italy these ordinances presuppose four principal factors: (i) urgency and necessity (they deal with urgent problems not covered by ordinary regulatory measures); (ii) contingency (they tackle extraordinary and unforeseeable situations); (iii) temporaneity (their application has a limited time-scale, and after a certain period things revert to normal); (iv) proportionality (they pursue the public interest with the least possible sacrifice of private interest) (Vandelli, 2008; Razzano, 2008).

With the modifications introduced in Italy by Decree no. 92 of 2008 on "urgent measures in the field of public security" - namely the Pacchetto Sicurezza [security package], converted into Law no. 125 of 2008 - the ordinance assumed new functions and characteristics.

Firstly, there was an increase in the areas in which ordinances might be employed. Notably, their use was extended to the field of urban safety and security. Ordinances may thus now apply, for example, to all situations that allegedly favour crime; or those that impede circulation, or detract from the city's "image", such as vagrancy, prostitution or begging: in short, behaviour that allegedly disturbs or annoys citizens. In fact, the Ministerial Decree defines the concept of urban security "very vaguely, as a public good that has to be defended at local level through the improvement of civic rules, and with the aim of improving living conditions in urban centres and strengthening social cohesion" (Recasens et al. 2013, p. 371).

Secondly, since Decree no. 92 an ordinance can be applied in a manner no longer determined by contingent and urgent factors. Furthermore, the requisite limited timescale has also disappeared.

\subsection{Diffusion and application}

Under the powers granted to them by Decree no. 92 of 2008, the mayors of many Italian towns have used ordinances as the standard means to regulate behaviour in public spaces, largely justifying their decisions on the basis of concerns for public decorum and safety.

A census carried out by the national survey group Cittalia - Fondazione ANCI ricerche (2009) covering August 2008 to August 2009 documented 788 ordinances on matters of urban security adopted by 445 municipalities. ${ }^{6}$ In $56 \%$ of the cases, these ordinances involved small to medium-sized cities (with between 5,000 and 50,000 inhabitants).

Of the ordinances documented, $69 \%$ were applied in the north of Italy, $11 \%$ in central Italy, $12 \%$ in the south, and $8 \%$ in the islands. ${ }^{7}$ Lombardy was the region with the greatest number of councils that resorted to this regulating device (127 separate councils, totalling 237 ordinances). But in percentage terms, the Veneto, Emilia Romagna, and Tuscany regions are those with the largest number of councils issuing ordinances.

The areas to which these ordinances applied were in particular: consumption of alcoholic beverages (13.6\%), prostitution (13\%), vandalism or damage to public or private property $(9.4 \%)$, serving food and/or beverages $(8 \%)$, rubbish dumping (7.6\%), begging (7.4\%), noise (6\%), camping $(6 \%)$. As regards those affected by the ordinances, $68 \%$ applied to the entire population; $15 \%$ to a specific "category" (such as shop-owners); and 17\% to specific "subjects".

Regarding the types of territory affected, in $60 \%$ of cases the ordinance applied to the council's entire jurisdiction, $20 \%$ to generic types of spaces (e.g., all parks), $20 \%$ to particular roads or squares (e.g., road A, square B). As concerns the period of validity, many ordinances do not include a specific date of expiry.

In most cases, any violation of the ordinance entails a fine - ranging on average between 150 and 500 euros. Only in a few cases is a legal penalty envisaged (Cittalia Fondazione ANCI Ricerche 2012).

\section{Discussion and evaluation: An analysis of the spatial dimension and implications of municipal ordinances}

Since the Decree no. 92 of 2008 was issued, the use of ordinances to regulate behaviour in public spaces has spread throughout the country, regardless of the political leanings of the administration involved. ${ }^{8}$ In a significant number of cases, the ordinance is intended to advance either directly or indirectly - a certain idea of the "good" (and a certain life-style), independently of actual harm to other individuals.

One "conception of the good" is an idea of what renders life pleasant and worth living. Each individual follows a more or less precise conception of what gives meaning to life. An individual's conception of a good life includes his/her main aims and goals in life, ideas on how to spend time and money, as well as specific tastes concerning everyday choices (Waldron, 1993). A particular life-style derives from a certain conception of the good. In the classical liberal tradition - which we follow here - the central idea is that the State must defend the right of each person to pursue the conception of the good life that he or she prefers, providing only that no tangible harm is directly caused to others (Larmore, 1996; Rawls, 1993). In this perspective it is not harmful to adopt a life-style that does not satisfy the desires, preferences or tastes of others.

Conversely, as we shall see, many ordinances are in fact targeted on certain life-styles (in themselves) and not on tangible harms (to others). This applies, for example, to certain ordinances concerning the consumption of 
alcohol, sale and consumption of food and beverages, the functioning of places of worship, prayer in public places, the language to be used in public events and on shop signs, expression of cultural features, leafleting, gathering signatures, prostitution, camping, and dossing, etc.

\subsection{Ordinances applied to all the city's public spaces}

In most cases ordinances are applied to all public spaces (within the council's territory).

It is worth starting the discussion from a simple observation: the fact that an individual possesses a body with physical extension requires the use of space for any type of activity (Logan and Molotch, 1987). This fact may seem banal, but it is hardly irrelevant to people who are in a situation of "no-property", namely without a private space of their own - a home, for instance. As Jeremy Waldron (1993), p. 313 notes, one way to describe the difficulties of homelessness is to observe that there is no place governed by a private property rule where the homeless are allowed to be. The point is that all actions necessarily involve a spatial component of some kind. If follows that someone who is not allowed to remain anywhere is precluded from all forms of activity, and is perforce deprived of freedom (ibid.). ${ }^{9}$ For individuals without property, public space is an essential element of their existence: it is the only place in which they can perform certain vital functions (sleep, eat, and satisfy other physiological needs).

In Italy this type of problem occurs in ordinances (around 10\% of the total) that apply to sleeping outdoors (in the sense of dossing somewhere improvised), for example by banning people from using sleeping-bags in public areas, or from sleeping in their cars parked on the street. The aim of such ordinances is usually to prevent homeless people from loitering on council land. ${ }^{10}$

In short: for people in a "no-property" situation, the prohibition of certain acts in public spaces is tantamount to banning them from performing those functions at all when the public authority does not provide an alternative. Consider sleeping in the street: if sleeping rough is banned and there are no alternatives provided by the public administration, certain categories of individuals are basically banned from sleeping altogether. As Waldron (2000), p. 397 writes, in the case of an individual who owns a home, compliance with an ordinance prohibiting sleeping in public places is merely a matter of "relocation"; but, for an individual who has no home, compliance with this kind of ordinance "would mean that he must not sleep (for there is now no place where his sleeping is permissible)".

To quote Waldron (2000), p. 394 again: If everyone in our cities had access to private accommodation in which to sleep, care for themselves, and so on, then public spaces could be regulated in the following way: "Since everyone would have access to a private home, activities deemed particularly appropriate to the private realm - activities like sleeping, copulating, washing, urinating and so forth could be confined to that realm. Public places could be put off-limits to such activities, and dedicated instead to activities that complemented those that citizens performed in their own homes". But this is not appropriate for public spaces in a city where there are homeless people. In such a setting, public spaces have to be regulated in light of the recognition that some people "have no alternative but to be and remain and live all their lives in public. For such persons, there is an unavoidable failure of the complementarity between the use of private space and the use of public space, and ... we are simply not in a position to use that complementarity as a basis for regulation" (ibid., p. 395).

The above objections in no way gainsay the problems that some of the ordinances aim to tackle (e.g., the problem of homelessness). Nor are we claiming that people should always be allowed to carry out certain activities in public - such as sleeping in the streets or fulfilling physiological needs. Nevertheless, in cases where there is no viable alternative provided by the public authorities (e.g., dormitories, camping areas, traveller camps, public urinals, etc.), the prohibition on the entire council territory of vital behaviours is a dubious undertaking: it is detrimental to the right to personal freedom, and in certain cases risks ratifying forms of discrimination against "undesirable" classes of people and life-styles.

The problem is that in many cases the prohibition of certain behaviours has paradoxically become more severe in parallel with the reduction of alternatives provided by the authorities. Not long ago many Italian cities had public urinals/washrooms; these facilities have gradually disappeared while penalties for relieving oneself in public have become harsher (as regards the US, compare with Waldron, 2000, pp. 383-384).

To conclude, the aim of certain ordinances is to keep homeless people out of the council's territory. The limitation of certain conduct in all public spaces within a council's jurisdiction causes a "criminalisation" of certain individuals whereby certain categories of people are proscribed from "existing" and "functioning" as human beings in that area (Mitchell, 1995 and Mitchell 1997).

A similar reasoning applies to travellers (Roma and itinerant Sinti). Such people have no private space of their own, except perhaps a camper or caravan. As a consequence, through ordinances of a certain kind, they too are often barred from staying - even temporarily - on a council's territory. ${ }^{11}$ Likewise, ordinances that ban begging on council territory follow a similar logic (Rossi, 2010). ${ }^{12}$ (To be noted is that, according to Italian law, the practice of "non-intrusive" begging is not a crime: Constitution Court sentence no. 519 of 1995). ${ }^{13}$ 


\subsection{Ordinances applied to specific portions of a city's public space}

Certain problems discussed in the previous section carry less weight when the prohibitions in question apply only to specific portions of the council's territory, meaning that certain functions and activities are banned from an assigned area, but not in others.

The issue in this case is the legitimacy of establishing different sets of rules for areas essentially of a similar nature. This does not include provisions intended to address temporary situations affecting a specific area of the city (such as excluding traffic on the occasion of a special event). Here the ordinance establishes a sort of permanent sub-zoning of public space: this applies to numerous ordinances banning the consumption of alcoholic beverages, or public assemblies, or loitering in specific public areas of Italian cities. ${ }^{14} \mathrm{~A}$ number of ordinances even restrict access to certain public spaces on the basis of age, residential address, or number of people in the gathering. ${ }^{15}$

If the aim is effectively the one usually cited - namely to prevent littering or breach of the "peace" - then to our mind there is no justification for applying such rules and bans only to specific areas of the city. This selective application encourages a division of the city into some zones in which certain normal activities are allowed and others in which they are prohibited. The upshot is that the average citizen's understanding of what is permitted and what not is fragmented, particularly when there are rarely clear indications (e.g. street signage) of the rules applying to the area in question. ${ }^{16}$

\section{Conclusions}

\subsection{Urban space and life-styles}

Many of the ordinances lay down rules on access to, and behaviour in, public spaces for general and generic use, such as streets, pavements, plazas, and so forth. These spaces can be termed "stricto sensu public spaces". ${ }^{17}$ Stricto sensu public spaces are those whose "publicness" is paramount by definition, so that any possible limitation is kept to an absolute minimum, and tolerance (i.e. the widest possible expression of plurality and respect for individual lifestyles: McKinnon, 2006; Walzer, 1997) to a maximum. In such places all access and behaviour should be tolerated, irrespective of their content, provided that they are not detrimental to the public nature of the space in question.

It is consequently crucial to identify what possible side-effects arising from certain activities might be considered detrimental to the use of public spaces. Debate on this intricate and complex issue is currently ongoing. Nonetheless, we accept two points that are closely interrelated: first, specific conceptions of the good life should not in themselves be the presuppositions for particular regulations (Moroni, 2012a and Moroni 2012b); second, the behaviour regulated should be the cause of evident negative external effects, namely direct and tangible forms of harm (Moroni, 2011). In brief, public regulation must acknowledge, and facilitate, the many different lifestyles that exist.

Yet some ordinances seem to regulate both access to, and action in, stricto sensu public spaces according to specific conceptions of the good life. They regulate behaviours which as such do not generate any noticeable negative externalities. Instead of trying to deflect possible harmful effects, in most of these situations the ordinance targets behaviours deemed unacceptable in themselves. The true purposes of such ordinances are therefore to hinder certain types of groups from converging on council territory, and to impede certain life-styles.

\subsection{Problems (substantive and procedural)}

As we have seen, in Italy in recent years municipal ordinances have been widely adopted as standard tools with which to regulate behaviour in public spaces, and they have often been applied excessively, and at times bizarrely. ${ }^{18}$ In many cases, this kind of application has generated two types of problems.

The first concerns "procedure". Here we have a tool - the municipal ordinance - devised as an extraordinary and emergency measure (and consequently issued through mayoral fiat without passing through the customary municipal decision-making procedures) being used instead as a means to establish ordinary regulations. This issue becomes even more serious when such measures are adopted for crucial questions that raise issues of tolerance: as an act that carries the mayor's authority, the ordinance per se hardly seems a suitable means with which to address such delicate issues, which would surely require wider debate within the traditional (elected) decision-making bodies. ${ }^{19}$ Indeed, from a constitutional standpoint, in Italy the municipal ordinance cannot introduce further - or diverse - prohibitions not already covered by the law (Corvaja 2010). ${ }^{20}$ To accept otherwise would be tantamount to granting the mayor the power "to please himself", which would certainly clash with the very essence of the rule of law (Moroni, 2007).

The second problem is one of "substance". As outlined above, in some instances the regulation of public spaces is not applied to prevent possible negative side-effects, but on the basis of substantive conceptions of the good life: in certain cases, the aim is deliberately to block or hamper the presence on council land of specific types of people - and their life-styles - deemed undesirable (Roma, homeless people, members of some religion, etc.). ${ }^{21}$ Similarly, in some cases attempts are made to condition the use of public space according to the belief that one type of life-style is better than another. Any such pre-emptive application clashes with the traditional 
liberal notion of civic freedoms: in fact, in the cases cited, the purpose of such public regulation does not seem to be prevention of the negative effects of the actions of individuals in order to safeguard the freedoms of everyone; but rather expressly to promote certain lifestyles over others (Corvaja, 2010). It should be made clear that we are not advocating some naïve idea of totally open access to public space: any type of public space is characterised by some form of regulation of access to and behaviour within it (Chiodelli and Moroni, 2014). The problem lies in the contents of such regulations, and in their justification.

\subsection{Perspectives}

On 4 April 2011, with ruling no. 115, the Italian Constitutional Court ${ }^{22}$ declared unconstitutional the modifications introduced by Decree no. 92 of 2008 regarding the ordinary use of ordinances. The court declared that, in terms of their end-goals (public welfare and urban security) and targets (the persons present on a given territory), ordinances impinge on the general sphere of freedom of the individual. Although they are intended to safeguard important public assets, they impose severe restrictions on the persons concerned: and the Italian Constitution, based as it is on the fundamental principles of legality and democracy, states that no duty, whether personal or public, may be imposed unless backed by the law. It should be pointed out that a further issue underscored in the Constitutional Court's ruling concerns the unconstitutionality of applying different norms to different parts of the Italian territory, thereby giving rise to excessive disparity of treatment among citizens. The Court also emphasised the scant knowability and comprehensibility of ordinances.

The case is not closed, however (Manfredi 2012): ${ }^{23}$ despite the above ruling no. 115, various mayors have expressed their intent to return to the previous wider application of ordinances. This intent has also been expressed by some national political parties. Meanwhile a trend is emerging whereby the contents of those ordinances rejected by the constitutional ruling are being transferred to the traditional local regulations (e.g., building and land-use regulations, sanitary regulations). ${ }^{24}$ While this might resolve some of the procedural hurdles indicated above (the introduction of these regulations follow ordinary procedures), it would not address our cited perplexities about their substance (in particular, the problem of the excessive and unjustified prescription in terms of conceptions of the good life). ${ }^{25}$

\section{Endnotes}

${ }^{1}$ Some parts of this article are based on Chiodelli and Moroni (2013).

${ }^{2}$ For a brief history of measures adopted regarding street disorder in the United States, see Ellickson (1996). For an analysis of the situation in Canada, see for example Hermer and Mosher (2002), Valverde (2009). On the case of Seattle, see Beckett and Herbert (2010).

${ }^{3}$ See for example the debate on the "revanchist city" (Smith, 1996) and the "carceral city" (Davis, 1990). For a critical reading of this debate, see for example De Verteuil (2012) and De Verteuil et al. (2009).

${ }^{4}$ For example: "Municipal law certainly governs persons, and even specific groups of persons, and not only dispossessed or marginal groups: but it does so in a different manner than the criminal law or constitutional rights law. Local authorities govern persons as well as pieces of land and buildings, but generally avoid governing through the category of 'person' [...]. Municipal rules and regulations generally govern through categories, such as 'use' and 'activity', that are somewhat removed from personhood” (Valverde, 2005), p. 37.

${ }^{5}$ Among the earliest laws in Italy covering the issue and substance of ordinances was Law no. 2248 of 1865. Subsequent laws that returned to the matter (endorsing the traditional conception of the ordinance per se) include the following: Law no. 148 of 1915; Law no. 383 of 1934; Law no. 142 of 1990; Decree no. 267 of 2000 (Razzano, 2008). As we shall see below, more substantive modifications were introduced by Decree no. 92 of 2008.

${ }^{6}$ According to Pizzetti (2012), from 2008 to April 2011, the overall number of ordinances issued exceeded 1,600.

${ }^{7}$ For an analysis of the reasons for this difference in the distribution of municipal ordinances see Pizzetti (2012).

${ }^{8}$ For a detailed analysis of the use of municipal ordinances in some Italian cities (Milano, Padova, Firenze, Bari, and Reggio Calabria), see Galdi and Pizzetti (2012). For certain respects, see also Ambrosini (2013).

${ }^{9}$ See also Waldron (2000 and 2009). For a critical overview, see Blomley (2009).

${ }^{10}$ See for example the ordinances of Albisola Superiore (SV) (no. 36/2010), Altopascio (LU) (no. 2134/2007), Verona (no. 65/2007), Lecco (no. 235/2008), Viareggio (no. 84/ 2009), Ricaldone (AL) (no. 3/2010), Varese (no. 20/2008), Sanremo (IM) (no. 455/2009).

${ }^{11}$ This is what applies, for example, at Mariano Comense (CO), in ordinance no. 17/2010. Similar ordinances have been adopted by numerous other Italian councils. In some cases the reference to traveller groups is explicit (see ordinance no. 2875/2010 of Torino); in others reference is made only to single or groups of camper-vans or caravans, as in ordinance no. 93/2008 of Reggio Calabria, and no. 13/2008 of Chieti. Ordinance no. 20/2006 issued by the council of Basaglio (MI), allows only for the presence of camper-vans and caravans belonging to residents and their guests (with prior authorisation from the council administration).

${ }^{12}$ This is the case of ordinance no. 20/2008 in Varese. Numerous other councils have adopted an anti-begging ordinance of this kind. They usually apply to the entire 
council territory. In most cases specific forms of begging are banned; for example aggressive begging or forms that involve the use of animals: this is the case of Ordinance no. 30/2008 issued in Alessandria, no. 84/2009 in Viareggio (LU), no. 285/2009 in Imperia, no. 10/2009 in Alba (CN), no. 408/2010 in Limena (PD), and no. 16/2011 in Valenza (AL). In some cases, however, begging in itself is prohibited: Ordinance no. 234/2008 in San Giuseppe Vesuviano (NA), no. 86/2008 in Turbigo (MI), no. 886/2008 in Marcallo con Casone (MI).

${ }^{13}$ More complex but equally important in light of the questions discussed here is the case of municipal ordinances that prohibit the wearing of full Islamic veils in public areas (Lorenzetti, 2010). Depending on the case, this prohibition is instituted directly, with explicit reference made to the Islamic veil in the text of the ordinance, or indirectly through a ban on appearing in public with clothing that hinders immediate recognition of the person. Similar ordinances have been adopted by Novara (no. 36/ 2010), Azzano Decimo (PN) (no. 3/2009), Drezzo (CO) (no. 15/2009), Caronno Varesino (VA) (no. 5/2005), Codogné (TV) (no. 82/2010), and Varallo (nos. 99 and 100/2009). The reasons cited are often linked to public order and security. The justification of public order is somewhat weak, however: any member of the police forces would be empowered to demand identification, where necessary (the Italian magistracy has issued a variety of rulings in this regard - for example, the Tribunal of Cremona, 27 November 2008 - stating that public security needs can be addressed through identification procedures performed directly by the authorities). In the cases mentioned, the prohibitions and limitations of public access seem more intended to impose a conception of the good. Note, moreover, that if the concern is to avoid imposing a certain type of dress on people (women) who would voluntarily not accept it, the regulation of access to and behaviour in public spaces through ordinances is certainly not the right instrument to apply. For a discussion of this problem in general terms, see Galeotti (2002, pp. 115-136).

${ }^{14} \mathrm{On}$ the issue of assemblies and the public consumption of alcohol, see Ordinance no. 34/2008 in Assago (MI). For the consumption of alcohol, see Padova (no. 53/ 2010), Verona (no. 61/2010), Bari (no. 162/2009).

${ }^{15}$ For example, Ordinance no. 25/2009 of Albisola Superiore imposed a ban on the transit through certain areas of the town centre (on weekends between 3.15 and 6.00) on all non-residents. The mayor of Sanremo, after banning (Ordinance no. 408/2009) anyone from sitting on certain (physical) "elements" in a town square, then conceded that persons aged 60 and over and children under 12 were allowed to do so. In some cities, ordinances have been issued that impose a ban on any form of loitering by groups of people (three or more) in specific public areas at certain hours of the night. This is the case for example of Assago (MI) (no. 34/2009), and Opera (MI) (no. 98/2009).

${ }^{16}$ For similar cases regarding areas from which certain individuals are excluded, see Beckett and Herbert (2010). For a comparison between two different approaches to the "zoning" of public spaces (one favourable, the other against it), see Ellickson (1996) and Mitchell (2003, pp. 211-222). For a discussion of this problem in general terms, see Rosen (1999).

${ }^{17}$ Distinguishing them from other categories of public spaces, definable as "special public spaces", in which greater limitations apply for obvious reasons to do with their specific functions, such as schools, libraries, hospitals, etc. (see Chiodelli and Moroni, 2014).

${ }^{18}$ In Ascoli Piceno, for example, Ordinance no. 62/ 2011 bans the collecting and throwing of used confetti; again in Ascoli Piceno, ordinance no. 368/2010 orders the mowing of lawns to ensure a uniform height of grass of no more than $20 \mathrm{~cm}$. The mayor of Capri has used ordinance (no. 10/2011) as a means to impose the DNA testing of dog faeces on the streets so as to establish the dog owners and fine them. In Varallo, Ordinance no. 102/2010 imposes a complete ban throughout the town of any form of insult to the Catholic religion, in the name of public security and order.

${ }^{19}$ Hence municipal ordinances are administrative acts devoid of the guarantees typical of administrative procedure (Bellavista, 2012).

${ }^{20}$ This is the "principle of legality in the formal sense" of administrative acts (Manfredi, 2012).

${ }^{21}$ Lorenzetti (2010) calls such bans "subjective", because they are directly or indirectly aimed at specific populations.

${ }^{22}$ In reaction to the anti-begging ordinance no. 91/2009 issued by the council of Selvazzano Dentro (PD).

${ }^{23}$ Consider also that a year after the Constitutional Court's ruling, no modification has been made to the text of the law on ordinances in compliance with the Court's instructions (Pizzetti, 2012).

${ }^{24}$ See Cittalia - Fondazione ANCI Ricerche (2012); in reference to the restrictive regulations on ethnic restaurants, see Magrassi (2010).

${ }^{25}$ For an in-depth discussion of the problem as tackled in other countries, see Beatley (1994, pp. 211-226).

Competing interest

The authors declare that they have no competing interest.

\section{Authors' contributions}

This article is the result of joint research undertaken by the two authors. The final written version of sections 1 , and 4 can be attributed to SM, and that of sections 2 and 3 to FC. Both authors read and approved the final

manuscript. 


\section{Author details}

${ }^{1}$ Department of Architecture and Urban Studies, Milan Polytechnic, via Bonardi 3 - 20133, Milano, Italy. ${ }^{2}$ Gran Sasso Science Institute, viale Francesco Crispi 7 - 67100, I'Aquila, Italy.

Received: 24 October 2013 Accepted: 2 April 2014

Published: 20 June 2014

\section{References}

Ambrosini M (2013) "We are against a multi-ethnic society": policies of exclusion at the urban level. Ethnic Racial Stud 36(1):136-155

Beatley T (1994) Ethical land use. Principles of policy and planning. The John Hopkins University Press, Baltimore

Beckett K, Herbert S (2010) Banished. The new social control in urban America. Oxford University Press, Oxford

Bellavista M (2012) Libertà versus sicurezza? In: Benvenuti S, Di Fonzo P, Gallo N, Giupponi TF (eds) Sicurezza pubblica e sicurezza urbana. Il limite del potere di ordinanza dei sindaci stabilito dalla Corte costituzionale. Franco Angeli, Milano

Blomley N (2007) How to turn a beggar into a bus stop: Law, traffic and the "function of the place". Urban Stud 44(9):1697-1712

Blomley N (2009) Homelessness, right, and the delusions of property. Urban Geogr 30(6):577-590

Carmona M, Tiesdell S, Heath T, Oc T (2010) Public places. Urban spaces. Elsevier, Amsterdam

Chiodelli F, Moroni S (2013) Città, spazi pubblici e pluralismo. Quaderni di Scienza Politica 1:125-144

Chiodelli F, Moroni S (2014) Typology of spaces and topology of toleration: City, pluralism, ownership. J Urban Aff 36(2):167-181

Cittalia - Fondazione ANCI ricerche (2009) Oltre le ordinanze. I sindaci e la sicurezza urbana. http://www.cittalia.it/index.php/welfare-e-societa/item/1777-oltre-leordinanze-i-sindaci-e-la-sicurezza-urbana. Accessed 12 March 2012

Cittalia - Fondazione ANCI Ricerche (2012) Per una città sicura. Dalle ordinanze agli strumenti di pianificazione e regolamentazione della convivenza cittadina. http://www.cittalia.it/images/file/Cittalia_pubblicazione_Per\%20una \%20citta\%20sicura(1).pdf. Accessed 23 June 2013

Corvaja F (2010) Esiste una libertà "innominata" da tutelare? Ordinanze sindacali "creative" e libertà individuale. Le Regioni 38(1-2):34-48

Davis M (1990) City of Quartz. Verso, New York

De Verteuil G (2012) Does the punitive need the supportive? A sympathetic critique of current grammars of urban injustice. Antipode, doi:10.1111/anti.12001

De Verteuil G, May I, von Mahs J (2009) Complexity not collapse: Recasting the geographies of homelessness in a "punitive" age. Prog Hum Geogr 33(5):646-666

Doherty J, Busch-Geertsema V, Karpuskiene V, Korhonen J, O'Sullivan E, Sahlin I, Tosi A Petrillo A, Wygnanska J (2008) Homelessness and exclusion: Regulating public space in European Cities. Surveill Soc 5(3):290-314

Ellickson RC (1996) Controlling chronic misconduct in city spaces. Yale Law J 105:1665-1248

Galdi A, Pizzetti F (eds) (2012) I sindaci e la sicurezza urbana. Le ordinanze sindacali e i loro effetti, Donzelli, Roma

Galeotti A (2002) Toleration as recognition. Cambridge University Press, Cambridge

Gehl J (1996) Life between buildings: Using public space. Arkitektens Forelag, Copenhagen

Hermer J, Mosher J (eds) (2002) Disorderly people. Law and the politics of exclusion in Ontario. Fernwood Publishing, Halifax

Larmore C (1996) The morals of modernity. Cambridge University Press, Cambridge

Logan JR, Molotch HL (1987) Urban fortunes. The political economy of place. University of California Press, Berkeley

Lorenzetti A (2010) II divieto di indossare "burqa" e "burqini". Che "genere" di ordinanze? Le Regioni 38(1-2):349-365

Madanipour A (2003) Public and private spaces of the city. Routledge, London

Madanipour A (ed) (2010) Whose public space? International case studies in urban design and development. Routledge, London

Magrassi M (2010) Le c.d. ordinanze "anti-kebab". Le Regioni 38(1-2):325-332

Manfredi G (2012) Principio di legalità e poteri di ordinanza nella sentenza della corte Costituzionale n. 115 del 2011. In: Benvenuti S, Di Fonzo P, Gallo N, Giupponi TF (eds) Sicurezza pubblica e sicurezza urbana. II limite del potere di ordinanza dei sindaci stabilito dalla Corte costituzionale. Franco Angeli, Milano

McKinnon C (2006) Toleration. A critical introduction, Routledge, London
Mitchell D (1995) The end of public space? People's park, definitions of the public, and democracy. Ann Assoc Am Geogr 85(1):108-133

Mitchell D (1997) The annihilation of space by law: The roots and implications of anti-homeless laws in the United States. Antipode 39(3):303-335

Mitchell D (2003) The right to the city. Social justice and the fight for public space. The Guilford Press, New York

Moroni S (2007) Planning, liberty and the rule of law. Plann Theory 6(2):146-163

Moroni S (2011) Land-use regulation for the creative city. In: Andersson DE, Mellander C, Andersson A (eds) Handbook of creative cities. Edward Elgar, Aldershot

Moroni S (2012a) Why nomocracy: Structural ignorance, radical pluralism and the role of relational rules. Prog Plan 77(2):46-59

Moroni S (2012b) Afterword: Ethical problems of contemporary cities. In: Basta C, Moroni S (eds) Ethics, design and planning of the built environment. Springer, Berlin

Pizzetti F (2012) Sicurezza urbana e ordinanze sindacali tra diritto e lealtà. In: Galdi A, Pizzetti F (eds) I sindaci e la sicurezza urbana. Le ordinanze sindacali e i loro effetti. Donizelli, Roma

Rawls J (1993) Political liberalism. Columbia University Press, New York

Razzano G (2008) Le ordinanze di necessità e urgenza nell'attuale ordinamento costituzionale. In: V V, A A (eds) Scritti in onore di Michele Scudiero. Jovene, Napoli

Recasens A, Cardoso C, Castro J, Nobili GG (2013) Urban security in southern Europe. Eur J Criminol 10(3):368-382

Rosen M (1999) Our nonuniform constitution: Geographical variations of constitutional requirements in the aid of community. Texas Law Rev 77 (5):1129-1164

Rossi S (2010) Note a margine delle ordinanze sindacali in materia di mendicità. Le Regioni 38(1-2):277-298

Smith N (1996) The new urban frontier: Gentrification and the revanchist city. Routledge, London

Staeheli LA, Mitchell D (2008) The people's property? Power, politics, and the public. Routledge, London

Teir R (1998) Restoring order in urban public spaces. Texas Rev of Law Polit 2:255-291

Valverde M (2005) Taking "land use" seriously: toward an ontology of municipal law. Law Text Culture 9(1):34-59

Valverde M (2009) Laws of the street. City Soc 21(2):163-181

Vandelli L (2008) Le ordinanze del sindaco in materia di sicurezza urbana. Astrid 87. http://www.astrid-online.it/Sicurezza-/Studi-ric/Nandelli_Ordinanze-sicurezzaurbana.pdf. Accessed 12 March 2012

Wacquant $L$ (2001) The penalization of poverty and the rise of neo-liberalism. Eur J Crim Policy Res 9(4):401-412

Waldron J (1993) Liberal rights. Cambridge University Press, Cambridge

Waldron J (2000) Homelessness and community. University of Toronto Law J $50: 371-406$

Waldron J (2009) Community and property - For those who have neither. Theor Inquiries Law 10(1):161-192

Walzer M (1997) On toleration. Yale University Press, New Haven

doi:10.1186/2195-2701-1-11

Cite this article as: Moroni and Chiodelli: Municipal regulations and the use of public space: local ordinances in Italy. City, Territory and Architecture 2014 1:11.

\section{Submit your manuscript to a SpringerOpen ${ }^{\circ}$ journal and benefit from:}

- Convenient online submission

- Rigorous peer review

- Immediate publication on acceptance

- Open access: articles freely available online

- High visibility within the field

- Retaining the copyright to your article

Submit your next manuscript at $>$ springeropen.com 